\title{
Mary Lyon og hypotesen om X-kromosominaktivering
}

\author{
Kvinner har to X-kromosomer, menn bare ett. Hvorfor har ikke kvinner også dobbelt opp av genproduktene som \\ bestemmes av gener på X-kromosomet? Den britiske genetikeren Mary Lyon beskrev i et kort leserbrev i Nature \\ i 1961 hypotesen om X-kromosominaktivering. Hypotesen, som for lengst er bevist, har hatt store konsekvenser \\ for vår forståelse av X-bundet arv og er et av de første kjente eksempler på epigenetisk regulering.
}

Karen Helene Ørstavik

k.h.orstavik@medisin.uio.no

Mary Frances Lyon ble født i England i 1925 og gikk bort første juledag 2014. Hun ble en av det 20. århundrets fremste genetikere. Ti år gammel vant hun en essaykonkurranse der premien var fire bøker om naturfag. Dette ble starten på hennes interesse for biologi, og hun valgte å studere zoologi og eksperimentell embryologi i Cambridge. Her var kvinnene i sterkt mindretall - det var bare 500 kvinner mot over 5000 menn. Selv om de fulgte de samme forelesningene og kursene som mennene, var det først i 1948 at kvinner offisielt fikk adgang til universitetet. Derfor fikk Mary Lyon bare en såkalt titulær grad da hun tok sin eksamen i 1946 (1).

Hun tok sin ph.d.-grad ved universitetet i Edinburgh i 1950. Der arbeidet hun med genetiske studier av mus, særlig genetiske stråleskader, som det var stor interesse for $i$ tiden etter den annen verdenskrig. En av hennes veiledere skaffet henne midler til postdoktorstudier fra Medical Research Council (MRC), som, i motsetning til andre finansieringskilder, ga samme lønn til kvinner som til menn (2). Senere flyttet hun til MRC Harwell i Oxfordshire, hvor hun arbeidet frem til hun ble pensjonist i 1990 .

Hun fortsatte imidlertid å være svært aktiv. 80 år gammel skrev hun som eneforfatter en elegant oversiktsartikkel om mulige mekanismer for X-kromosominaktiveringen (3), og hun fortsatte å arbeide i laboratoriet flere dager i uken. En bygning i Harwell bærer hennes navn, The MRC Mary Lyon Centre. Det er i dag et internasjonalt senter for genetiske studier av mus (4).

\section{Lyon-hypotesen}

Det var studier av mus som førte til Mary Lyons hypotese om X-kromosominaktivering, som er det hun er mest kjent for. Hun arbeidet med dyr som hadde mutasjoner i X-bundne gener som bestemmer pels- fargen. De affiserte hannmusene hadde ensfarget, unormal pels, mens hunnmusenes pels var flekkete, med en blanding av normal og unormal farge. Hennes forklaring var at bare det ene av de to X-kromosomene i hver enkelt celle var aktivt. Flekkene med unormal farge representerte celler hvor det muterte X-kromosomet var aktivt, flekkene med normal farge celler hvor det normale X-kromosomet var aktivt (5).

Hennes hypotese fikk etter hvert navnet Lyon-hypotesen, og selve fenomenet omtales gjerne som lyonisering. Lyon-hypotesen går ut på at det ene av de to X-kromosomene hos kvinnelige pattedyr blir inaktivert $i$ alle kroppens celler på et tidlig tidspunkt og at denne inaktiveringen er tilfeldig og permanent i den enkelte celle.

X-kromosominaktiveringen har vist seg å være langt mer komplisert enn det man først trodde. Omkring 15\% av genene på $\mathrm{X}$-kromosomet blir ikke inaktivert, andre gener blir bare delvis inaktivert. Dette varierer både mellom kvinner og fra vev til vev hos samme kvinne $(6,7)$.

\section{Klinisk betydning}

$\mathrm{X}$-kromosominaktiveringen er en stokastisk prosess. De fleste kvinner vil derfor ha en femti-femti-fordeling av celler der det paternelle X-kromosomet er aktivt og celler der det maternelle X-kromosomet er aktivt.

Av tilfeldige årsaker vil den ene av de to celletypene dominere hos noen kvinner. De har en såkalt skjev X-inaktivering. Lyoniseringen kan forklare hvorfor kvinner som er arvebærere av X-bundet sykdom kan ha både lette og alvorlige symptomer.

Kvinner som er arvebærere av hemofili kan ha noe økt blødningstendens, men de kan også en sjelden gang ha like alvorlig sykdom som menn med hemofili. Forklaringen på dette er at det muterte X-kromosomet er det aktive i de fleste av kroppens celler (8). Dette er et eksempel på epigenetisk genregulering. Forandringen i genekspresjonen, i dette tilfellet manifestasjon av hemofili, skyldes X-kromosominaktiveringen, ikke forandringer i selve DNA-et.
Det samme fenomenet som Mary Lyon observerte i musene med flekkete pels, kan vi for øvrig se hos kvinner som er arvebærere av X-bundet anhidrotisk ektodermal dysplasi. Tilstanden innebærer blant annet mangel på svettekjertler. De kvinnelige arvebærerne kan ha flekker av hud som mangler svettekjertler (9). X-kromosominaktiveringsmønsteret bestemmes i dag ved enkle PCR-baserte metoder og kan være til stor nytte i utredning av familier med arvelig sykdom (10).

Det er en fordel for kvinner å ha to Xkromosomer. Hvis det er noe galt med det ene, kan de benytte det andre, de har en «backup». De er derfor stort sett beskyttet mot sykdommer som skyldes mutasjoner på X-kromosomet. Det at kvinner har to X-kromosomer og menn bare ett, kan også være én av flere forklaringer på den overdødeligheten blant menn som finnes i alle aldersgrupper $(1,11)$.

\section{Kvinnelig forsker i det forrige århundre}

I forbindelse med Mary Lyons bortgang har alle de tunge tidsskriftene, som Nature (12), Cell (2) og The Lancet (13), publisert storslagne nekrologer. Disse er interessant lesning. De forteller ikke bare om hennes betydelige vitenskapelige innsats, men også noe om den motstanden denne lille (hun var bare litt over $150 \mathrm{~cm}$ høy) og tilsynelatende beskjedne forskeren møtte. I forbindelse med lanseringen av hypotesen syntes en av hennes opponenter at hun var for ung og ikke godt nok etablert til å fremme en så dristig og omfattende hypotese, og kanskje også at en så betydningsfull teori ikke kunne komme fra en kvinne $(1,2)$.

Mary Lyon var en meget stillferdig og tilbakeholden person. Men bak hennes milde vesen skjulte det seg en sterk karakter med bestemte meninger når det gjaldt forskning. Ble hun spurt om noe, tok det gjerne lang tid før hun svarte. Under denne stillheten ble man advart mot å snakke, for da var hennes briljante hjerne $\mathrm{i}$ arbeid (2). Hun 


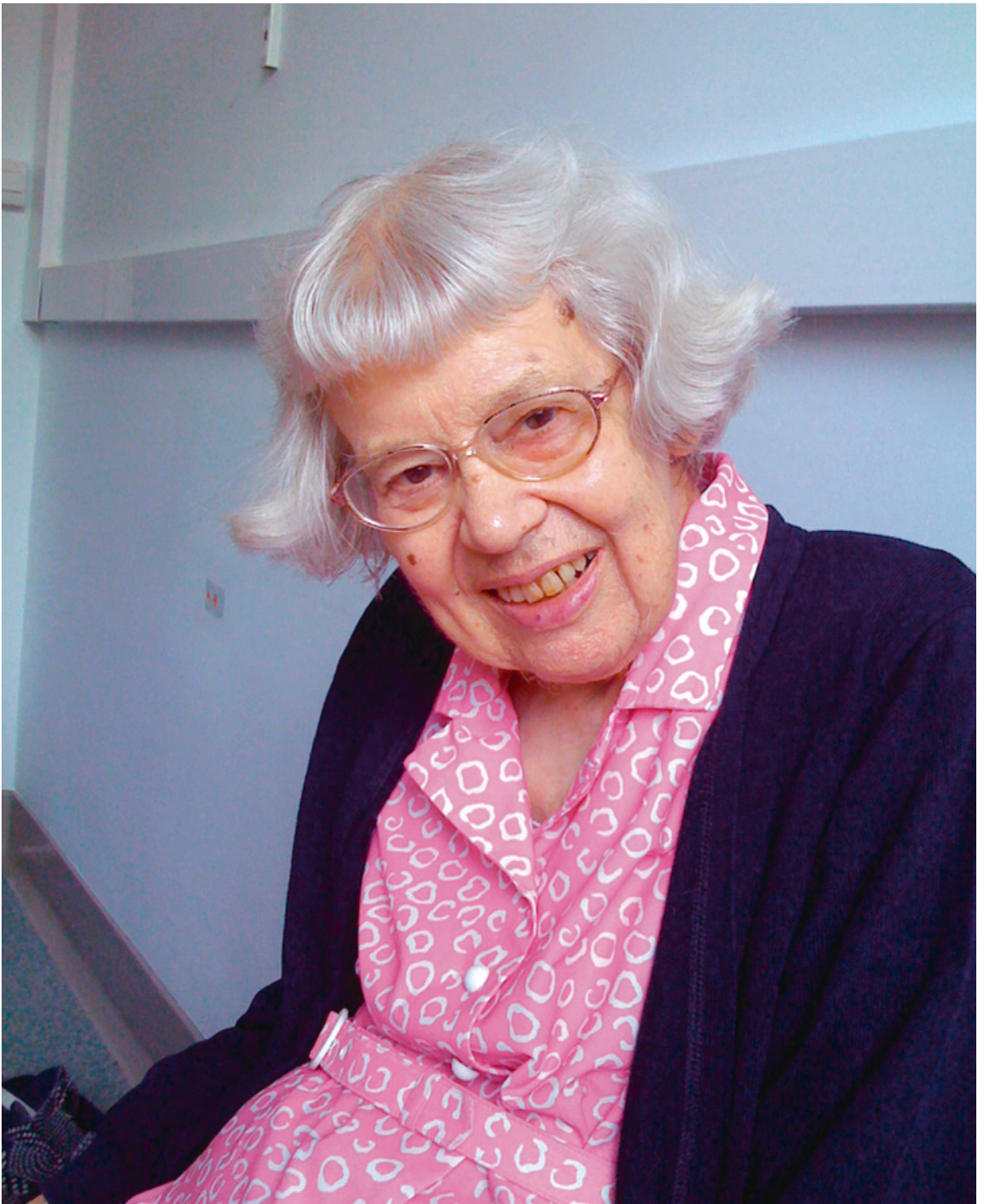

Foto: Jane Gitschier/Creative Commons

var også kjent for å være snill og hjelpsom, og hun var en stor kilde til inspirasjon for yngre kolleger.

Mary Lyon vant en rekke priser for sitt arbeid, men ikke mange nok i forhold til hva hun hadde oppnådd, sies det. Og flere av prisene ble gitt etter at hun var blitt pensjonist. Noen har også undret seg over at hun verken fikk nobelprisen eller ble adlet (14). Men fordi hennes navn er knyttet til hennes store hypotese, vil denne lille kjempen heldigvis ikke bli glemt.

\section{Karen Helene Ørstavik (f. 1937)}

er spesialist i medisinsk genetikk. Hun har vært overlege ved Avdeling for medisinsk genetikk, Oslo universitetssykehus, og er professor emerita ved Institutt for klinisk medisin, Universitetet i Oslo.

Forfatter har fylt ut ICMJE-skjemaet og oppgir ingen interessekonflikter.

\section{Litteratur}

1. Harper PS. Mary Lyon and the hypothesis of random $X$ chromosome inactivation. Hum Genet 2011; 130: 169-74.

2. Fisher EM, Peters J. Mary Frances Lyon (1925-2014) Cell 2015: 160: 577-8.

3. Lyon MF. Do LINEs have a role in X-chromosome inactivation? J Biomed Biotechnol 2006; 2006 59746.

4. Nightingale K. Remembering Mary Lyon and her impact on mouse genetics.

www.insight.mrc.ac.uk/2015/02/03/remembering mary-lyon-and-her-impact-on-mouse-genetics (24.4.2015).

5. Lyon MF. Gene action in the X-chromosome of the mouse (Mus musculus L.). Nature 1961; 190: 372-3.

6. Lyon MF. No longer 'all-or-none'. Eur J Hum Genet 2005; 13: 796-7.

7. Wu H, Luo J, Yu H et al. Cellular resolution maps of $X$ chromosome inactivation: implications for neural development, function, and disease. Neuron 2014; 81: 103-19.

8. Ørstavik KH, Ørstavik RE, Schwartz M. Skewed $X$ chromosome inactivation in a female with haemophilia B and in her non-carrier daughter: a genetic influence on $\mathrm{X}$ chromosome inactivation? J Med Genet 1999; 36: 865-6.

9. Happle R. X-chromosome inactivation: role in skin disease expression. Acta Paediatr Suppl 2006; 95 : $16-23$.

10. Ørstavik KH. X chromosome inactivation in clinical practice. Hum Genet 2009; 126: 363-73.

11. Christensen K, Orstavik KH, Vaupel JW. The X chromosome and the female survival advantage: an example of the intersection between genetics, epidemiology and demography. Ann N Y Acad Sci 2001; 954: 175-83.

12. Rastan S. Mary F. Lyon (1925-2014). Nature 2015; 518: 36 .

13. Watts G. Mary Frances Lyon. Lancet 2015; 385 : 768

14. Gitschier J. The gift of observation: an interview with Mary Lyon. Interview by Jane Gitschier. PLoS Genet 2010; 6: e1000813.

Mottatt 2.5. 2015 og godkjent 17.5. 2015. Redaktør: Lise Mørkved Helsingen. 